American Journal of Environmental Sciences 5 (3): 434-443, 2009

ISSN 1553-345X

(C) 2009 Science Publications

\title{
Water Quality and Planktonic Communities in Al-Khadoud Spring, Al-Hassa, Saudi Arabia
}

\author{
Adel A. Fathi and Mohammed A. Al-Kahtani \\ Department of Biology, College of Science, King Faisal University, Saudi Arabia
}

\begin{abstract}
Problem statement: Al-Khadoud spring is one of the most important water resources in AlHassa Governorate, Saudi Arabia. However, much of its biotic information is still unknown. This study presented preliminary ecological information of this aquatic body. The aim of this research was to study the water characteristics and the planktonic organisms inhibiting Al-Khadoud spring and its irrigational channels for a period of 1 year. Approach: A regular visit was monitoring the spring over a period of 1 year (June 2007 to may 2008). Physico-chemical characteristics of spring water were determined. Quantitative and qualitative analysis of Plankton (Phytoplankton or zooplankton) were also investigated. Results: All the water quality variables measured showed considerable seasonal variation. The data of this study showed that there were marked seasonal differences in the quantitative and qualitative composition of the phytoplankton communities in Al-Khadoud spring and its irrigation canal. The changes in total algal counts throughout the investigation coincided closely with in Chlorophyceae abundance. Thirty six species were identified allover the period of the investigation. Out of these, 9 species belong to Chlorophyceae, 17 belong to Bacillariophyceae, 7 to Cyanophyceae and 3 to Euglenophyceae. Cyclotella meneghiniana Kützing, Nitzschia closterium Ehernberg, Fragilaria capucina Desmazieres, Surirella ovalis Breb, Actinastrum sp., Chlorella vulgaris Beyerinck, Scenedesmus quadriquda Breb, Oscillatoria sp. and Oscillatoria subbrevis Schmidle were observed in a high rank of occurrence. The phytoplankton crop showed a remarkable increase as compared with the previous records. The data showed that the zooplanktonic fauna identified in this aquatic body is a typical of the permanent freshwater and brackish water. Eleven species were recorded, 5 belonged to Cladoceran, 4 belonged to Rotifera and 2 belonged to Chironomid. Zooplankton species like Thermocyclops hyalinus, Mesocyclops sp., Moina micrura, Brachionus caudatus, B. falcatus and Filina longiseta were recorded at all sites investigated allover the study period. The scarcity of zooplankton species from Al-Khadoud spring and its irrigation canal could be due to the nature of these reservoirs as both receiving reuse-drainage and treated sewage water. Conclusion: These results indicated that after receiving water from the outlets either treated sewage water or of re-use drainage water, the spring water had an obvious increase in electrical conductivity, COD, total alkalinity, nitrates, phosphorus, chloride and potassium. These features indicated pollution with organic wastes, increased salinity and deteriorated oxygenated state. Based on this we can say that all these factors can be affected both soil and plants cultivated in the area of Al-Hassa.
\end{abstract}

Key words: Al-Khadoud spring, macrophytes, phytoplankton, zooplankton

\section{INTRODUCTION}

Plankton dynamics or the time dependent changes in plankton biomass are the result of a complex interplay of physical, chemical and biological processes. The seasonal cycles of biological parameters are usually driven by factors referred to as physical biological ${ }^{[1]}$. Therefore, plankton diversity in relation to water quality is a well practiced protocol, accepted all over the world, which help to describe an ecological system and is a measure of community pattern ${ }^{[2,3]}$. Plankton diversity is controlled by seasonal changes as well as by the rate at which plant nutrients are supplied.

Primary production has performed by chlorophyllbearing plants ranging from the tiny phytoplankton to the giant kelps through the process of photosynthesis. Zooplankton plays an important role as secondary producers and together with phytoplankton; they support the vast assemblages of marine food chain with all their diversity and complexity. Data on chlorophyll pigments,

Corresponding Author: Adel A. Fathi, Department of Biology, College of Science, King Faisal University, 31982-Al-Hassa, P.O. Box 55076, Saudi Arabia Tel: 0096557001682 
phytoplankton and zooplankton has regarded as a sound basis for environmental appraisal of ecosystems ${ }^{[4]}$.

Saudi Arabia is a hot, dry country with a high level of development of all kinds. Demand for water increases continually, resources remain limited. The municipal water supply is mainly desalinated water and partly wadi groundwater $^{[5]}$. Al-Hassa's Province is one of the largest oases in the world and located in the southern part of the eastern region of Saudi Arabia. An agricultural area of Al-Hassa receives the highest solar energy load $1200 \mathrm{~W} \mathrm{~m}^{-2}$ in the world ${ }^{[6]}$, thus providing favorable arid ecosystems for planktonic and wild plant to grow ${ }^{[7]}$.

Whitton et $a l^{[8]}$ studied the water chemistry and algal vegetation of streams in the Asir Mountains, Saudi Arabia. Okla studied the algal microfacies in upper tuwaiq mountain limestone (Upper Jurassic) near Riyadh $^{[9]}$. Hussain and Sadiq studied the metal chemistry of irrigation and drainage waters of Al-Hassa Oasis of Saudi Arabia and its effects on soil properties $^{[10]}$. Hussain and Khoja studied the intertidal and subtidal blue-green algal mats of open and mangrove areas in the Farasan Archipelago (Saudi Arabia), Red Sea ${ }^{[11]}$. Al-Homaidan described planktonic algae and water chemistry of various water bodies ${ }^{[12,13]}$. Hussain et al. ${ }^{[14]}$ and Al-Homaidan and Arif ${ }^{[15]}$ studied the seasonal succession of bloom-forming algae over a period of 3 consecutive years (1992-1995) in relation to the trophic changes taking place in a semi-permanent rain-fed pool at Al-Kharj, Saudi Arabia ${ }^{[14,15]}$. On the other hand quantitative surveys of the intertidal macrobiota were conducted between 1991 and 1995 in the Saudi Arabian Gulf along Permanent Transect Lines (PTLs) by Jones et al. ${ }^{[16]}$. Al-Aidaroos et al. ${ }^{[17]}$ studied the occurrence and abundance of zooplankton in sewage polluted coastal areas of Jeddah in Al-Arbaeen and Al-Shabab lagoons (Saudi Arabia). Shaikh et al. ${ }^{[18]}$ studied the Phytoplankton ecology and production in the Red Sea off Jiddah. Baker and Hosny studied the zooplankton diversity and abundance in Half Moon Bay, Saudi coastal waters, Arabian Gulf ${ }^{[19]}$. Recently, Al-Fredan and Fathi investigated the Edaphic algae in Al-Hasa, Eastern region, Saudi Arabia ${ }^{[20]}$.

Al-Khadoud spring is one of the most important water resources in Al-Hassa, however; much of its biotic information is still unknown. The aim of this research is to study the water characteristics and the planktonic organisms inhibiting Al-Khadoud spring and its irrigational channels for a period of 1 year.

\section{MATERIALS AND METHODS}

Site description: Al-Hassa lies in the south of the Kingdom's Eastern region and is bounded by the Al-
Dahna and the Al-Daman deserts. It is situated between $25^{\circ} 05^{\prime}$ and $25^{\circ} 40^{\prime}$ Northern latitude and $49^{\circ} 55^{\prime}$ Eastern longitude. The Al-Hassa oasis is the largest oasis in the Kingdom of Saudi Arabia and the municipality of AlHassa constitutes the largest administrative area in the Kingdom. Al-Hassa has a dry, tropical climate, with a five-month summer and a relatively cold winter. It enjoys the benefit of copious reserves of underground water, which has allowed the area to develop its agricultural potential. Al-Hassa's water mainly originates from an underground source through a number of artesian springs. Al-Khadoud's spring is one of the most important water resources in Al-Hassa Region and plays an important role in agricultural activities in the area. It is located nearly $5.0 \mathrm{~km}$ Northwest of King Faisal University main campus.

Sampling: A regular visit was monitoring the spring over a period of 1 year (June 2007 to may 2008). Subsurface water samples were taken on each visit from 4 sites. Site $\mathrm{I}$ is the main water basin of Al-Khadoud spring which situated between $25.22775^{\circ} \mathrm{N}$ and $49.36444^{\circ} \mathrm{E}$. The other three sites collected from the irrigational channel of the spring. Site II that was located $3 \mathrm{Km}$ north of the main spring (situated between $25.223427^{\circ} \mathrm{N}$ and $49.37465^{\circ} \mathrm{E}$ ), Site III: located $5 \mathrm{Km}$ north of Al-Khadoud spring basin (situated between $25.33654^{\circ} \mathrm{N}$ and $49.37998^{\circ} \mathrm{E}$ ) and Site IV: located $10 \mathrm{Km}$ of the spring basin (situated between $25.23569^{\circ} \mathrm{N}$ and $49.38817^{\circ} \mathrm{E}$ ).

Physico-chemical characteristics: Temperature, $\mathrm{pH}$ and conductivity, total dissolved salts and dissolved oxygen were measured at each location. $\mathrm{pH}$ was measured using a $\mathrm{pH}$ meter (370 $\mathrm{pH}$ meter Jenway, UK), conductivity and total dissolved salts using a calibrated Conductivity Meter (470 Conductivity meter, Jenway, UK). Dissolved oxygen was measured according to the Winkler method ${ }^{[21]}$. Total alkalinity, chloride, nitrate-N, phosphate-P, sulfate, major cations and Chemical Oxygen Demand (COD) were determined according to Water and wastewater examination manual ${ }^{[22]}$. Sodium and potassium concentrations were determined photometrically by flame emission ${ }^{[23]}$. Results were calculated as mean values of triplicate measurements made on each water sample from each of the four sampling stations. The calculated values are the mean of three replicates; the standard deviation was less than $5 \%$ of the mean value.

Quantitative and qualitative analysis of Plankton: Chlorophyll's content of water was determined according to the method described by Strickland and 
Parsons ${ }^{[21]}$. For Phytoplankton analysis, $1.5 \mathrm{~L}^{-1}$ water samples were fixed in the filed with acid Lugol's solution ( $1 \mathrm{~mL} \mathrm{~L}^{-1}$ sample). Samples were then allowed to settle for at least $36 \mathrm{~h}$, where after the supernatant was siphoned off and the remaining volume was adjusted to $100 \mathrm{~mL}$. This $100 \mathrm{~mL}$ sample was kept at $4^{\circ} \mathrm{C}$ until analysis. Phytoplankton counts were done using a Wild inverted microscope following the Utermöhl technique ${ }^{[24]}$. For counting, the simplified methods described by Willen and Hobro-Willen was followed $^{[25,26]}$. The counts of phytoplanktonic algae (unicellular, colonial or filamentous) expressed as cells per $\mathrm{mL}$. The algal taxa dentified according to standard references ${ }^{[27-30]}$. The appropriate statistic in Brillouin's index ${ }^{[31]}$ was used for quantitative analysis of species diversity of the phytoplankton. On the other hand, Zooplankton samples were collected on each sites with a net mesh size of $80-100 \mu \mathrm{m}$ and preserved in isopropyl alcohol. Estimation of zooplankton density was made by counting $1 \mathrm{~mL}$ sub-sample of the wellmixed standard sample in a Sedgwick Rafter counting chamber. The counts were converted to number of cells or organisms per cubic meter of water. Zooplankton species were identified according to standard references $^{[32,33]}$.

\section{RESULTS AND DISCUSSION}

It is well known that, the physical and Chemical characteristics controlling life in aquatic habitats, either saline or brackish water, lead to the appearance of special types of biota $^{[34-36]}$.

The annual values of the measured parameters of Al-Khadoud spring and its irrigation canal shown in Table 1 varied for the different sites except temperature which was nearly the same in all sites throughout the period of study. The water of Al-Khadoud spring (Sites I and II) before receiving either treated sewage water or re-use drainage was characterized by low conductivity, low total dissolved salts and low carbon oxygen demand while the mean values of other parameters were always the least among other sites.

The data of Table 1 shows that the average water temperature of Al-Khadoud spring and its irrigation canal was subjected to seasonal variations. The temperature of water reached its minimum in winter $\left(16^{\circ} \mathrm{C}\right)$ while the maximum $\left(26.9^{\circ} \mathrm{C}\right)$ was recorded in summer samples. The water temperature of AlKhadoud spring and its irrigation canal generally followed that of the air, due to the shallow depth ${ }^{[37-39]}$. In the present investigation the spring and its irrigation canal did not show proper thermal stratification, as it is extremely shallow (maximum depth $0.5 \mathrm{~m}$ ). Allott reported that thermal stratification is weak in the shallowest aquatic systems ${ }^{[40]}$. Generally, it can be said that any increase or decrease in standing crop of phytoplankton at Al- Khadoud spring and its irrigation canal seemed to be strongly correlated with fluctuation in water temperature. This is in accordance with results obtained by some other authors ${ }^{[10,34,36,38,41]}$.

Change in $\mathrm{pH}$ value was always in the alkaline side. It fluctuated between 7.74 in winter at site III and 8.42 in summer at site IV. Generally, this general tendency to the alkaline side may be due to the increased photosynthetic activity of planktonic algae, or to the chemicals nature of water ${ }^{[34,35,42]}$. The lowest $\mathrm{pH}$ and alkalinity values recorded in this investigation may be due to greater amount of discharging waste water and also to the decomposition of plankton and organic matter $^{[43-46]}$.

Table 1: The physico-chemical characteristics of Al-Khadoud spring water during the investigation period

\begin{tabular}{|c|c|c|c|c|c|c|c|c|c|c|c|c|c|c|c|c|}
\hline \multirow[b]{3}{*}{ Parameters } & \multicolumn{16}{|c|}{ Seasons/sites } \\
\hline & \multicolumn{4}{|c|}{ Summer } & \multicolumn{4}{|c|}{ Autumn } & \multicolumn{4}{|c|}{ Winter } & \multicolumn{4}{|l|}{ Spring } \\
\hline & 1 & 2 & 3 & 4 & 1 & 2 & 3 & 4 & 1 & 2 & 3 & 4 & 1 & 2 & 3 & 3 \\
\hline Temperature ${ }^{\circ} \mathrm{C}$ & 24.20 & 24.90 & 22.80 & 22.50 & 20.00 & 21.00 & 20.80 & 21.10 & 18.60 & 18.80 & 18.00 & 18.10 & 19.20 & 19.20 & 19.40 & 19.20 \\
\hline $\mathrm{pH}$ & 7.95 & 7.65 & 7.71 & 8.00 & 7.88 & 7.90 & 7.89 & 8.22 & 8.02 & 7.75 & 7.74 & 7.92 & 8.00 & 7.99 & 7.72 & 8.01 \\
\hline Conductivity $(\mathrm{mS})$ & 2.31 & 2.96 & 5.20 & 5.55 & 2.20 & 2.30 & 4.39 & 4.44 & 2.36 & 2.35 & 4.55 & 4.54 & 2.66 & 2.20 & 4.56 & 4.76 \\
\hline $\operatorname{TDS}\left(\mathrm{g} \mathrm{L}^{-1}\right)$ & 1.38 & 1.77 & 3.11 & 3.42 & 1.38 & 1.37 & 2.64 & 2.66 & 1.42 & 1.41 & 2.76 & 2.72 & 1.12 & 1.38 & 2.78 & 3.29 \\
\hline Dissolved $\mathrm{O}_{2}\left(\mathrm{~g} \mathrm{~L}^{-1}\right)$ & 9.00 & 5.80 & 6.23 & 7.50 & 6.50 & 4.20 & 4.00 & 8.00 & 9.21 & 6.64 & 6.00 & 8.20 & 14.20 & 10.50 & 10.70 & 12.30 \\
\hline Alkalinity $\left(\mathrm{mg} \mathrm{L}^{-1}\right)$ & 129.00 & 124.00 & 101.00 & 137.00 & 67.00 & 113.00 & 191.00 & 194.00 & 90.00 & 115.00 & 129.00 & 134.00 & 53.00 & 130.00 & 142.00 & 169.00 \\
\hline Chloride $\left(\mathrm{mg} \mathrm{L}^{-1}\right)$ & 454.00 & 412.00 & 562.00 & 976.00 & 434.00 & 472.00 & 658.00 & 1160.00 & 434.00 & 444.00 & 538.00 & 960.00 & 450.00 & 452.00 & 742.00 & 1240.00 \\
\hline Nitrate-N $\left(\mathrm{mg} \mathrm{L}^{-1}\right)$ & 2.10 & 2.70 & 2.50 & 4.20 & 1.70 & 2.00 & 2.70 & 1.90 & 2.10 & 2.30 & 3.74 & 2.40 & 1.90 & 1.92 & 4.70 & 3.60 \\
\hline Phosphate-P $\left(\mathrm{mg} \mathrm{L}^{-1}\right)$ & 0.75 & 0.73 & 0.78 & 0.38 & 0.35 & 0.75 & 2.75 & 2.75 & 0.52 & 0.52 & 2.75 & 2.75 & 0.75 & 0.75 & 2.14 & 2.14 \\
\hline Sulphate-S $\left(\mathrm{mg} \mathrm{L}^{-1}\right)$ & 298.00 & 299.00 & 322.00 & 348.00 & 301.00 & 295.00 & 308.00 & 335.00 & 295.00 & 290.00 & 314.00 & 355.00 & 288.00 & 287.00 & 312.00 & 350.00 \\
\hline Sodium $\left(\mathrm{mg} \mathrm{L}^{-1}\right)$ & 255.00 & 254.00 & 412.00 & 455.00 & 237.00 & 240.00 & 324.00 & 362.00 & 229.00 & 234.00 & 315.00 & 357.00 & 234.00 & 235.00 & 315.00 & 425.00 \\
\hline Potassium (mg L $\left.{ }^{-1}\right)$ & 39.50 & 38.40 & 25.80 & 27.10 & 31.30 & 32.00 & 21.50 & 26.40 & 23.00 & 22.00 & 21.00 & 21.50 & 25.20 & 25.20 & 27.40 & 25.20 \\
\hline Calcium $\left(\mathrm{mg} \mathrm{L}^{-1}\right)$ & 172.00 & 176.00 & 150.00 & 143.00 & 165.00 & 166.00 & 154.00 & 154.00 & 158.00 & 157.00 & 158.00 & 151.00 & 162.00 & 160.00 & 161.00 & 163.00 \\
\hline Magnesium (mg L$\left.{ }^{-1}\right)$ & 71.40 & 70.00 & 71.10 & 68.20 & 65.40 & 62.50 & 67.10 & 66.40 & 69.00 & 68.70 & 68.00 & 65.80 & 70.60 & 70.50 & 71.00 & 70.20 \\
\hline $\mathrm{COD}\left(\mathrm{mg} \mathrm{L}^{-1}\right)$ & 10.10 & 11.20 & 25.50 & 40.40 & 10.50 & 12.00 & 22.50 & 30.30 & 10.00 & 11.80 & 22.80 & 27.20 & 9.90 & 10.20 & 26.10 & 33.90 \\
\hline
\end{tabular}


The conductivity and the Total Dissolved Salts (TDS) of the investigated sites water were higher in summer (5.55 m sec and $3.42 \mathrm{~g} \mathrm{~L}^{-1}$, respectively) but dropped to a minimum level through winter and spring ( $2.16 \mathrm{mS}$ and $1.12 \mathrm{~g} \mathrm{~L}^{-1}$, respectively). On the other hand, site III and site IV were characterized by high electrical conductivity and TDS. The highest value of its electrical conductivity could be attributed mainly to the high pollution levels in water, resulted from the high nutrient loads of wastewater ${ }^{[10,35,39,42]}$. On the other hand the fluctuations of salinity of North Egyptians lakes from time to time could be explained by the differences of the input amount of drainage water ${ }^{[36]}$.

Dissolved oxygen is an important parameter for identification of different water masses. The oxygen content of the investigated lake water tended to be higher in summer $\left(17.00 \mathrm{mg} \mathrm{L}^{-1}\right)$ at site I and lower in winter $\left(4.00 \mathrm{mg} \mathrm{L}^{-1}\right)$ at site III. The relatively high concentrations of dissolved oxygen recorded in this study (summer) could be mainly attributed to light intensity rather than photosynthetic activity of phytoplankton $^{[41]}$ due to the increased photosynthetic activity of phytoplankton populations. In this respect, some author noticed that oxygen super saturation due to photosynthetic activity is often encountered in regions with abundant phytoplankton ${ }^{[47]}$.

Total alkalinity of Al-Khadoud spring and its irrigation canal was found to fluctuate in a narrow range. However, site IV was characterized by higher concentrations of alkalinity in compare to the other investigated sites, this increases may be due to the bacterial decomposition of organic substrates coming with the re-use drainage water receiving by this site $^{[38,39,48,49]}$.

Chloride attained their maximum in spring at site IV (1240 $\left.\mathrm{mg} \mathrm{L}^{-1}\right)$ and dropped to their minimum in summer at site II $\left(412 \mathrm{mg} \mathrm{L}^{-1}\right)$. The high concentrations of chloride recorded in this study could be mainly attributed to waste water discharge. It seemed probable that ions play significant role in biomass and standing crop. Some author stated that chlorides appear to limit algal production directly in nature, but in the form of $\mathrm{NaCl}^{[35]}$.

The maximum value of nitrate was found in summer at site IV $\left(4.20 \mathrm{mg} \mathrm{L}^{-1}\right)$ and the minimum value in autumn at site $\mathrm{I}\left(1.7 \mathrm{mg} \mathrm{L}^{-1}\right)$. The highest values of nitrate-N reflect the direct effect of the agriculture runoff ${ }^{[50]}$, while the lowest values of nitrate$\mathrm{N}$ are indicative of phytoplankton uptake. On the other hand, phosphate-P content tended to be high in all investigation period. In general site I and II were characterized by low phosphate-P content, but sites III and IV by high phosphate-P content. The recorded high phosphate-P values probably due to the release of great amounts of adsorbed phosphate from the re-use drainage water ${ }^{[39,50,51]}$. On the other hand the lowest values of phosphate concentrations could be attributed to the vigorous uptake by the plankton ${ }^{[34,51]}$.

Monovalent and divalent cations play very important role in the productivity of inland water. Calcium and magnesium are reported to be of importance for plankton production ${ }^{[52]}$. In the present study the values of divalent (calcium and magnesium) and monovalent cations (sodium and potassium) were relatively high at all samples, irrespective of some minor fluctuations in seasonally readings. Levels of calcium and magnesium were found to fluctuate within the ranges of 143-172 and 71.4-62.5 $\mathrm{mg} \mathrm{L}^{-1}$, respectively. On the other hand the concentrations of sodium were found to be higher throughout the study period, which exceeded those of calcium, magnesium and potassium in the spring water. It fluctuated from $455 \mathrm{mg} \mathrm{L}^{-1}$ (in summer at site IV) to $229 \mathrm{mg} \mathrm{L}^{-1}$ (in winter at site I). Generally, of Al-Khadoud spring water showed rather higher values of sodium content. Despite its major role in algal growth and photosynthesis, there are only a few instances of either magnesium deficiency or toxicity in lakes ${ }^{[53]}$. Magnesium is usually present in aquatic system in large amounts relative to plant needs. Both sodium and potassium play important role in the productivity of water ${ }^{[54,53]}$. However some authors suggested that the amounts of sodium, calcium and chloride determine the species present rather than quantitative development of phytoplankton ${ }^{[55]}$.

The chemical oxygen demand was taken in the present study as a measure of the oxygenated state and additionally the amount of organiclmatter in water as well. The data of this study show that COD tended to be higher in site IV throughout the investigated period in comparison to the other studied sites, especially in summer $\left(40.4 \mathrm{mg} \mathrm{L}^{-1}\right)$. The increase in COD could be attributed to the high organic matter content that produces about poor oxygenated state of water resulted from the discharging of untreated waste water ${ }^{[34,39,56,57]}$.

Generally, after receiving water from the outlets either treated sewage water or of re-use drainage water, the spring water at sites III and IV had an obvious increase in electrical conductivity, COD, total alkalinity, nitrates, phosphorus, chloride and potassium in comparison with sites I and II (i.e., before receiving). These features indicate pollution with organic wastes, increased salinity and deteriorated oxygenated state. Based on this we can say that all these factors can be affected both soil and plants cultivated in the area of Al-Hassa. 


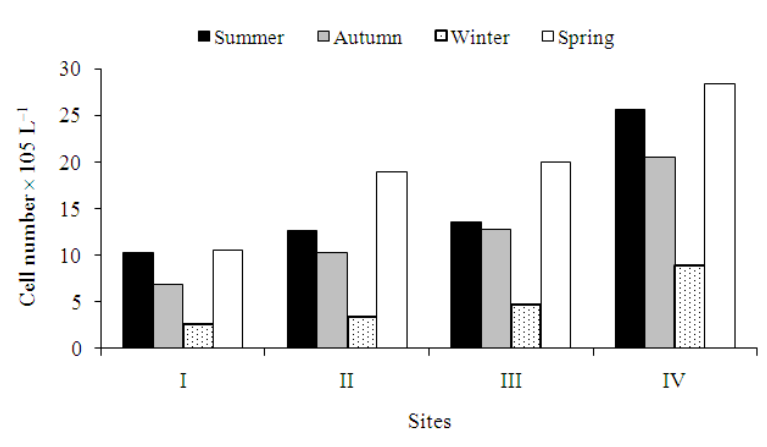

Fig. 1: Phytoplankton abundance (cell number $\times 10^{5} \mathrm{~L}^{-1}$ ) in Al-Khadoud's spring and its irrigation channel during the investigation period

Phytoplankton: It is well known that, the changes in physico-chemical characteristics of any water mass lead to concomitant qualitative and quantitative changes in phytoplanktonic organisms ${ }^{[35,36]}$.

On the other hand Chlorophyll content in spring exceeded that recorded in other samples (Fig. 4), which could be attributed to vigorous phytoplankton growth $^{[58]}$.

The data of this study shows that there are marked seasonal differences in the quantitative and qualitative composition of the phytoplankton communities in AlKhadoud spring and its irrigation canal (Table 3 and Fig. 1 and 2). In terms of total cell number the maximum count $\left(28.45 \times 10^{5}\right.$ cell $\left.\mathrm{L}^{-1}\right)$ was recorded in spring at site IV, whereas the lowest densities occurred in winter $\left(2.5 \times 10^{5}\right.$ cell $\left.\mathrm{L}^{-1}\right)$ at site $\mathrm{I}$ (Fig. 1$)$. The changes in total algal counts throughout the investigation coincided closely with in Chlorophyceae abundance.

Four algal groups were recorded throughout the investigation period, Bacillariophyceae, Chlorophyceae, Cyanophyceae and Euglenophyceae. (Table 2 and 3). The data of Fig. 2 shows that, at sites I, II and III the total percentage composition of the four main phytoplankton groups shows that Chlorophyceae dominated the phytoplankton of Al-Khadoud spring and its irrigation canal throughout the study period. Bacillariophyceae ranked second dominated. Ranking third were the Cyanophyceae, which were least abundant in the winter and spring. Euglenophyceae ranked fourth in order of dominance. On the other hand, the site IV was characterized by the dominated of Cyanophyceae in the summer and autumn, while Chlorophyceae was dominated in the winter and spring, while other algal groups at the same order of other investigated sites. It is worthy to mention that in summer and autumn samples some Euglenoids were recorded in a high abundance at site IV.

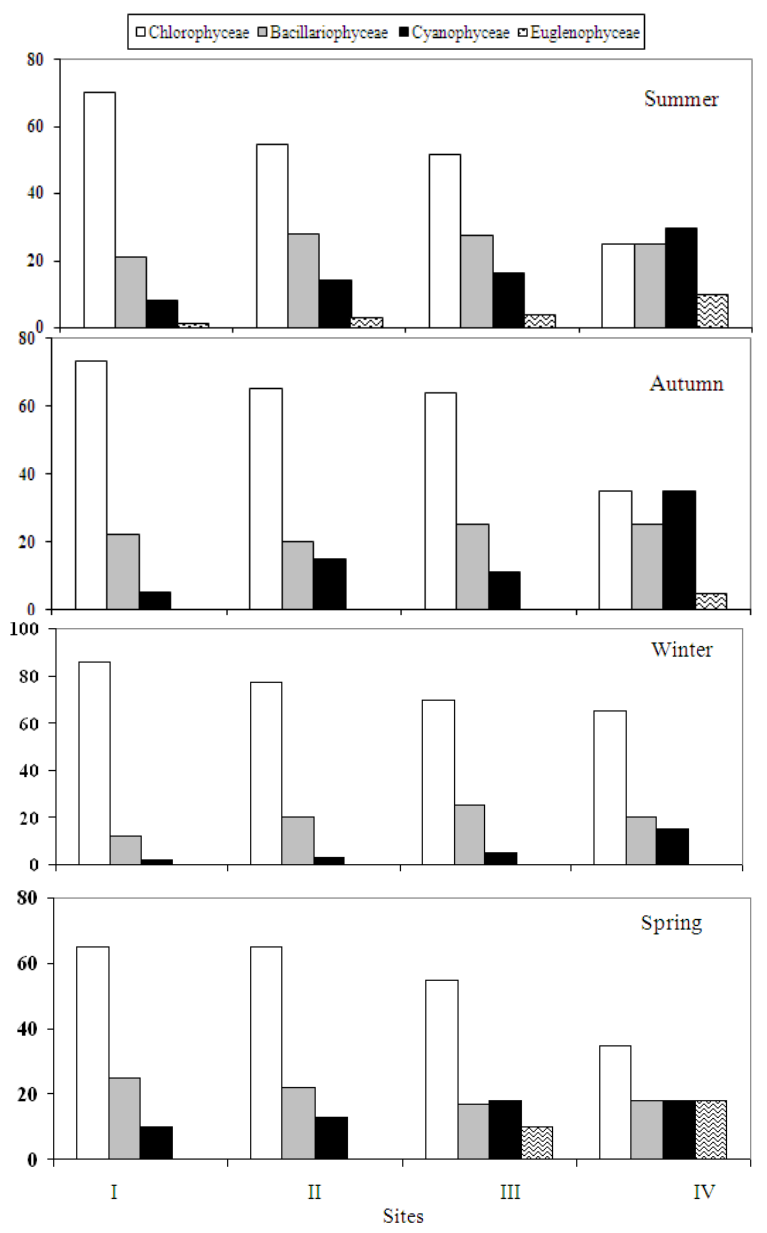

Fig. 2: The percentage composition of the main algal groups recorded in the phytoplankton of AlKhadoud's spring and its irrigation channel during the investigation period

Table 2: The chlorophyll's content of Al-Khadoud spring during the investigation period

\begin{tabular}{llllll}
\hline & & Season & & & \\
& & - & & & \\
Pigment content & Sites & Summer & Autumn & Winter & Spring \\
\hline Chlorophyll-a & 1 & $3.35 \pm 0.15$ & $2.01 \pm 0.15$ & $1.11 \pm 0.10$ & $4.24 \pm 0.20$ \\
$\left(\mu \mathrm{g} \mathrm{L}^{-1}\right)$ & 2 & $2.42 \pm 0.02$ & $2.04 \pm 0.05$ & $1.25 \pm 0.10$ & $4.68 \pm 0.20$ \\
& 3 & $2.22 \pm 0.10$ & $2.04 \pm 0.00$ & $1.22 \pm 0.05$ & $4.00 \pm 0.15$ \\
& 4 & $3.54 \pm 0.05$ & $3.05 \pm 0.00$ & $2.54 \pm 0.05$ & $5.24 \pm 0.08$ \\
Chlorophyll-b & 1 & $1.04 \pm 0.02$ & $0.48 \pm 0.00$ & $0.32 \pm 0.05$ & $1.31 \pm 0.01$ \\
$\left(\mu \mathrm{g} \mathrm{L}^{-1}\right)$ & 2 & $1.02 \pm 0.02$ & $0.42 \pm 0.01$ & $0.28 \pm 0.00$ & $1.52 \pm 0.01$ \\
& 3 & $0.91 \pm 0.02$ & $0.42 \pm 0.01$ & $0.25 \pm 0.00$ & $1.01 \pm 0.01$ \\
& 4 & $1.55 \pm 0.05$ & $0.56 \pm 0.08$ & $0.45 \pm 0.00$ & $2.34 \pm 0.05$ \\
Chlorophyll-c $^{-1}$ & 1 & $0.08 \pm 0.00$ & $0.02 \pm 0.00$ & $0.05 \pm 0.00$ & $0.22 \pm 0.00$ \\
$\left(\mu \mathrm{g} \mathrm{L}^{-1}\right)$ & 2 & $0.07 \pm 0.00$ & $0.05 \pm 0.00$ & $0.05 \pm 0.00$ & $0.18 \pm 0.01$ \\
& 3 & $0.07 \pm 0.00$ & $0.05 \pm 0.00$ & $0.04 \pm 0.05$ & $0.20 \pm 0.01$ \\
& 4 & $0.12 \pm 0.00$ & $0.08 \pm 0.00$ & $0.06 \pm 0.05$ & $0.33 \pm 0.02$ \\
\hline
\end{tabular}

Means \pm SD $(\mathrm{n}=3)$ 
Am. J. Environ. Sci., 5 (3): 434-443, 2009

Table 3: Relative occurrence of the phytoplanbkton on Al-Khadoud's spring and its irrigation channel during the investigation period

\begin{tabular}{|c|c|c|c|c|c|c|c|c|c|c|c|c|c|c|c|c|}
\hline \multirow[b]{3}{*}{ Algal species } & \multicolumn{16}{|c|}{ Seasons/sites } \\
\hline & \multicolumn{4}{|c|}{ Summer } & \multicolumn{3}{|c|}{ Autumn } & \multirow{2}{*}{4} & \multicolumn{4}{|c|}{ Winter } & \multicolumn{4}{|c|}{ Spring } \\
\hline & 1 & 2 & 3 & 4 & 1 & 2 & 3 & & 1 & 2 & 3 & 4 & 1 & 2 & 3 & 4 \\
\hline \multicolumn{17}{|l|}{ Bacillariophyceae (17 species): } \\
\hline $\begin{array}{l}\text { Amphora coffeoformis (Ag.) Kutz. } \\
\text { Anomoeoneis sphaerophora Ehr. }\end{array}$ & 1.0 & & & & & & & & 1.0 & & & 1.0 & & & & 1.0 \\
\hline Caloneis bacillum Grun. & & 2.0 & 1.0 & & 1.0 & 1.0 & & & 1.0 & 1.0 & & & 1.0 & 1.0 & & \\
\hline Caloneis pulchra Messikommer & & 1.0 & & & & 1.0 & & & 1.0 & & & & 2.0 & 2.0 & & \\
\hline Caloneis silicula (Ehr.) Cleve & & & & 1.0 & & & & & & & 1.0 & & & & 1.0 & 1.0 \\
\hline Cocconeis thumensis Meyer & 1.0 & & & & 1.0 & & & & & & & & 1.0 & 1.0 & & \\
\hline Cyclotella meneghiniana Kützing & 1.0 & 2.0 & 2.0 & 3.0 & 1.0 & 1.0 & 1.0 & 1.0 & 1.0 & 1.0 & 1.0 & 1.0 & 1.0 & 2.0 & 2.0 & 4.0 \\
\hline Cymbella amphioxys Cleve & 1.0 & & & & & & & & & & & & 1.0 & & & 1.0 \\
\hline Fragilaria capucina Desmaziéres & 1.0 & 3.0 & 3.0 & 3.0 & 1.0 & 1.0 & 2.0 & 1.0 & 1.0 & 1.0 & 1.0 & 1.0 & 1.0 & 2.0 & 3.0 & 4.0 \\
\hline Navicula confervacea Kutz & & & 1.0 & 1.0 & & & & 1.0 & & & & 1.0 & & & 3.0 & 2.0 \\
\hline Navicula cuspidata Kutz. & & & & 2 & & & & 2.0 & & & & 2.0 & & & & 2.0 \\
\hline Navicula sp. & 1.0 & & & & & & & & & & & & 1.0 & & & \\
\hline Nitzschia closterium Ehernberg & 1.0 & & 1.0 & 1.0 & 1.0 & & 1.0 & 1.0 & & & & & 1.0 & 2.0 & 3.0 & 4.0 \\
\hline Pleurosigma strigosum W. Smith & & & & 1.0 & & & & & & & & & & & & 1.0 \\
\hline Surirella ovalis Breb & 1.0 & 2.0 & 2.0 & 3.0 & 1.0 & 2.0 & 1.0 & 2.0 & 1.0 & 1.0 & 1.0 & 1.0 & 2.0 & 3.0 & 3.0 & 4.0 \\
\hline Synedra acus Kützing & & & & 1.0 & & & 2.0 & 1.0 & & & & 1.0 & & & 3.0 & 4.0 \\
\hline Tabellaria sp. & & 1.0 & 1.0 & 1.0 & & & & & & & & & & & 2.0 & 2.0 \\
\hline \multicolumn{17}{|l|}{ Chlorophyceae (9 species): } \\
\hline Actinastrum sp. & 1.0 & 1.0 & 2.0 & 3.0 & 1.0 & 1.0 & 1.0 & 1.0 & 1.0 & 1.0 & 1.0 & 1.0 & 2.0 & 3.0 & 4.0 & 4.0 \\
\hline Ankistrodesmus falcatus Ralfs & & & & 2.0 & & & & 1.0 & & & & 1.0 & & & & 3.0 \\
\hline Carteria multifilis Fres. & & & 1.0 & 1.0 & & & 1.0 & 1.0 & & & & & & & 1.0 & 1.0 \\
\hline Chlamydomonas sp. & 1.0 & & & 2.0 & & & & & & & & 1.0 & & & 1.0 & 2.0 \\
\hline Chlorella vulgaris Beyerinck & 2.0 & 2.0 & 2.0 & 2.0 & 1.0 & 2.0 & 2.0 & 2.0 & 1.0 & 1.0 & 1.0 & 1.0 & 2.0 & 3.0 & 3.0 & 4.0 \\
\hline Eudorina sp. & & & 1.0 & 2.0 & & & & & & & & & & & & \\
\hline Mougetia sp. & 4.0 & & & & 2.0 & & & & 1.0 & & & & 4.0 & & & \\
\hline Scenedesmus quadriquda Bréb. & & & 2.0 & 1.0 & & & 2.0 & 3.0 & & & & & & 1.0 & 3.0 & 4.0 \\
\hline \multirow{2}{*}{\multicolumn{17}{|c|}{ Cyanophyceae (7 species) }} \\
\hline & & & & & & & & & & & & & & & & \\
\hline Chroococcus turgidus Näg & & & 2.0 & 2.0 & & & 1.0 & 1.0 & & & & & & & 1.0 & 1.0 \\
\hline Cylindrospermum sp. & & & & 1.0 & & & & & & & & & & & & 1.0 \\
\hline Merismopedia elegans Braum & & & & 1.0 & & & & & & & & & & & & 1.0 \\
\hline Oscillatoria saneta Gomont & 1.0 & & & & 1.0 & & & & & & & 1.0 & & & & 1.0 \\
\hline Oscillatoria si & & & 1.0 & 1.0 & & & & & & & & 1.0 & & & & \\
\hline Oscillatoria subbrevis Schmidle & & & 2.0 & 4.0 & & & & & & & & 1.0 & & & 2.0 & 3.0 \\
\hline Oscillatoria sp. & 1.0 & 1.0 & 1.0 & 2.0 & 1.0 & & & & 1.0 & & & 1.0 & 1.0 & 1.0 & 2.0 & 3.0 \\
\hline \multicolumn{17}{|l|}{ Euglenophyceae ( 3 species) } \\
\hline Euglena acus Ehrenberg. & & & 2.0 & 3.0 & & & & & & & & & 1.0 & & 1.0 & 1.0 \\
\hline Euglena lavata Skuja & & & 1.0 & 2.0 & & & & & & & & & & & & 2.0 \\
\hline Euglena gracilis Klebs & & & & 1.0 & & & & & & & & & & & & 2.0 \\
\hline Species r & 14.0 & 9.0 & 18.0 & 26.0 & 11.0 & 8.0 & 10.0 & 13.0 & 10.0 & 6.0 & 6.0 & 15.0 & 14.0 & 11.0 & 18.0 & 30.0 \\
\hline Diversity Index (H) & 3.8 & 3.6 & 2.5 & 1.9 & 3.8 & 4.0 & 3.5 & 2.8 & 4.0 & 4.0 & 3.5 & 2.6 & 3.7 & 3.2 & 2.0 & 1.7 \\
\hline
\end{tabular}

The data included in Table 3 further revealed that a total of 36 species were identified allover the period of the investigation. Out of these, 9 species belong to Chlorophyta, 17 belong to Bacillariophyta, 7 to Cyanophyta and 3 to Euglenophyta. The maximum number of phytoplankton taxa on any one sampling period (30 species) occurred in spring at site IV, while the minimum (6 species) was in winter at sites II and III. Cyclotella meneghiniana Kützing, Nitzschia closterium Ehernberg, Fragilaria capucina Desmaziéres, Surirella ovalis Breb, Actinastrum sp., Chlorella vulgaris Beyerinck, Scenedesmus quadriquda Bréb,
Oscillatoria sp. and Oscillatoria subbrevis Schmidle were observed in a high rank of occurrence. Eight algal species were moderately common (Cyanophyceae and Bacillariophyceae). On the other hand 15 species were frequently recovered; most of them belong to Bacillariophycea and Euglenophyceae. The remaining recorded species were rarely recovered. Also found that some sites had been marked by the presence of some algal species, which appear linked to these sites especially in summer and spring. Site I was characterized by Mougetia sp., which can be attributed to the lack of water movement in this site. 
Am. J. Environ. Sci., 5 (3): 434-443, 2009

Table 4: Distribution of zooplanktonic fauna in water of Al-Khadoud spring and its irrigation canal over the study period

\begin{tabular}{|c|c|c|c|c|c|c|c|c|c|c|c|c|c|c|c|c|}
\hline \multirow[b]{3}{*}{ Zooplankton species } & \multicolumn{16}{|c|}{ Seasons/sites } \\
\hline & \multicolumn{4}{|c|}{ Summer } & \multicolumn{4}{|c|}{ Autumn } & \multicolumn{4}{|c|}{ Winter } & \multicolumn{4}{|c|}{ Spring } \\
\hline & 1 & 2 & 3 & 4 & 1 & 2 & 3 & 4 & 1 & 2 & 3 & 4 & 1 & 2 & 3 & 4 \\
\hline \multicolumn{17}{|c|}{ Cladoceran species (Crustacean): } \\
\hline Alona rectangula & & & & & & & + & & & & & + & & & & + \\
\hline Ceriodaphnia dubia & & & + & + & & & & & & & & & & & & + \\
\hline Mesocyclops sp. & + & + & + & + & + & + & + & + & + & + & + & + & + & + & + & + \\
\hline Moina micrura & + & + & + & + & + & + & + & + & + & + & + & + & + & + & + & + \\
\hline Thermocyclops hyalinus & + & + & + & + & + & + & + & + & + & + & + & + & + & + & + & + \\
\hline \multicolumn{17}{|l|}{ Rotifera species: } \\
\hline Alona rectangula & & & + & + & & & + & & & & & + & & & + & + \\
\hline Ceriodaphnia dubia & & & + & + & & + & + & & & & + & & & & & + \\
\hline Mesocyclops $\mathrm{sp}$. & + & + & + & + & + & + & + & + & + & + & + & + & + & + & + & + \\
\hline Moina micrura & + & + & + & + & + & + & + & + & + & + & + & + & + & + & + & + \\
\hline \multicolumn{17}{|c|}{ Chironomid species (Diptera): } \\
\hline Chironomus plumosus & + & & & + & & & & + & & & & & & & & + \\
\hline Corynoneura sp. & & & & + & & & & + & & & & & & & & + \\
\hline
\end{tabular}

On the other hand, site IV was characterized by the three recorded Euglena species. This could be due to the receiving of this sites huge amounts of wastewater (re-use drianage water), which contain high concentrations of organic materials specific to the growth of these algae ${ }^{[34,35]}$. Generally, the phytoplankton crop showed a remarkable increase as compared with the previous records ${ }^{[7]}$.

\section{CONCLUSION}

The data of Table 3 also shows that the maximum diversity index (4.0) was estimated on autumn at site II and on winter at sites I and II, while the minimum (1.7) was in summer at site IV. It should be noted that biological indices of species diversity, based mainly on the composition of phytoplankton have been proposed by Pilou and Nygaard may indicate the pollutional state of water ${ }^{[31,59]}$. There are several numerical attempts ${ }^{[60]}$ to express degrees of oligotrophy and eutrophy from a consideration of species complements rather than from nutrient levels ${ }^{[61]}$. Some workers believe that the biological estimation of the degree of eutrophication and pollution of aquatic ecosystems is probably more informative than chemical determinations ${ }^{[36,62]}$. According to the scales of Staub ${ }^{[63]}$, site I and II is indicates slight polluted in all seasons; site III slight polluted in autumn and summer, but light polluted in summer and spring; site IV moderate polluted throughout the study period.

Zooplankton: The zooplankton recorded at the four investigated sites of Al-Khadoud spring and its irrigation canal over the study period are shown in Table 4. The data shows that the zooplanktonic fauna identified in this aquatic body is a typical of the permanent freshwater and brackish water. Eleven species were recorded, 5 belonged to Cladoceran, 4 belonged to Rotifera and 7 belonged to Chironomid. Zooplankton species like Thermocyclops hyalinus, Mesocyclops sp., Moina micrura, Brachionus caudatus, B. falcatus and Filina longiseta were recorded at all sites investigated allover the study period. Other species were found to be fluctuated from sites to sites. Chironomidae species are poorly represented in the analyzed samples. This poverty is possibly the results of different modes of sampling. Indeed, the Chironomidea are often benthic forms and rarely found in surface water. Generally, the sites IV have shown the highest varieties of zooplankton compared with the other studied sites. The scarcity of zooplankton species from Al-Khadoud spring and its irrigation canal could be due to the nature of these reservoirs as both receiving drainage and treated water ${ }^{[64]}$.

\section{ACKNOWLEDGEMENT}

We thank Prof. Dr. Abdalaziz. A. Almulhem the Dean of Deanship of Scientific Research, King Faisal University and the Deanship members for financial support (Grant No: 8063).

\section{REFERENCES}

1. Harrison, P.J., N. Khan, K. Yin, M. Saleem, N. Bano, M. Nisa, S.I. Ahmed, N. Rizvi and F. Azam, 1997. Nutrient and phytoplankton dynamics in two mangrove tidal creeks of the Indus River delta, Pakistan. Mar. Ecol. Prog. Ser., 157: 13-19. http://www.intres.com/articles/meps/157/m157p013.pdf 
2. Magurran, A., 1988. Ecological Diversity and its Measurement. Cambridge University Press, England, ISBN: 0709935390, pp: 179.

3. Barnese, L.E. and C.L. Schelske, 1994. Effects of nitrogen, phosphorus and carbon enrichment on planktonic and periphytic algae in a soft water, oligotrophic lake in Florida, USA. Hydrobiologia, 277: 159-170.

http://cat.inist.fr/?aModele=afficheN\&cpsidt=3979 812

4. Abdul Azis, P.K., I.A. Al-Tisan, M.A. Daili, T.N. Green, A.G.I. Dalvi and M.A. Javeed, 2003. Chlorophyll and plankton of the Gulf coastal waters of Saudi Arabia bordering a desalination plant. Desalination, 154: 291-302.

http://cat.inist.fr/?aModele $=$ afficheN\&cpsidt $=1467$ 4525

5. Abu-Rizaiza, O.S., 1999. Modification of the standards of wastewater reuse in Saudi Arabia. Water Res., 33: 2601-2608. http://cat.inist.fr/?aModele $=$ afficheN\&cpsidt $=1861$ 808

6. Dreaver, K.R., M.S. Assed, Y.M. Makki and A.M. Turjoman, 1981. Investigation of the agroclimate and model formulation in Al-Hassa. Proc. Saudi Biol. Soc., pp: 35-47.

7. Al-Kahtani M.A., A.M. Youssef and A.A. Fathi, 2007. Ecological studies on Al-Khadoud spring, Al-Hassa, Saudi Arabia. Pak. J. Sci., 10: 4063-4068. http://www.ncbi.nlm.nih.gov/pubmed/19090280

8. Whitton, B.A., T.M. Khoja and I.A. Arif, 1986. Water chemistry and algal vegetation of streams in the Asir Mountains, Saudi Arabia. Hydrobiologia, 133: 97-106.

http://www.springerlink.com/content/r7811671582 48527/

9. Okla, S.M., 1987. Algal microfacies in upper tuwaiq mountain limestone (Upper Jurassic) near Riyadh. Saudi Arabia, 58: 55-61. http://cat.inist.fr/?aModele=afficheN\&cpsidt $=8112507$

10. Hussain, G. and M. Sadiq, 1991. Metal chemistry of irrigation and drainage waters of Al-Ahsa Oasis of Saudi Arabia and its effects on soil properties. Water Air Soil Pollut., 57-58: 773-783. http://www.springerlink.com/content/wx012q2724 130261/

11. Hussain, M.I. and T.M. Khoja, 1993. Intertidal and subtidal blue-green algal mats of open and mangrove areas in the Farasan Archipelago (Saudi Arabia), Red Sea. Botanica Mar., 36: 377-388. http://cat.inist.fr/?aModele $=$ afficheN\&cpsidt $=3853943$

12. Al-Homaidan, A.A., 1994. New records of freshwater green algae from South Western Saudi Arabia. Biol. Sci., 3: 29-47.
13. Al-Homaidan, A.A., 1994. Water chemistry and algal vegetation of reservoirs in southwestern Saudi Arabia. J. Univ. Kuwait (Sci.), 21: 51-60. http://md1.csa.com/partners/viewrecord.php?requester=g $\mathrm{s} \&$ collection $=\mathrm{ENV} \& \mathrm{recid}=3608913 \& \mathrm{q}=$ Water + chemistr $\mathrm{y}+$ and+algal+vegetation+of+reservoirs+in+southwestern + Saudi+Arabia\&uid=788100800\&setcookie $=$ yes

14. Hussain, M.I., T.M. Khoja and M. Guerlesquin, 1996. Chemistry, Ecology and seasonal succession of charophytes in the Al-Kharj Irrigation Canal, Saudi Arabia. Hydrobiologia, 333: 129-137. http://cat.inist.fr/?aModele=afficheN\&cpsidt $=2478901$

15. Al-Homaidan, A.A and I.A. Arif, 1998. Ecology and bloom-forming algae of a seni-permanent rainfed pool at Al-Khaji, Saudi Arabia. J. Arid Environ., 38: 15-25. DOI: 10.1006/jare.1997.0319

16. Jones, D.A., J. Plaza, I. Watt and M. AL Sanei, 1998. Long-term (1991-1995) monitoring of the intertidal biota of Saudi Arabia after the 1991 gulf war oil spill. Mar. Pollut. Bull., 36: 472-489. http://cat.inist.fr/?aModele=afficheN\&cpsidt=2318305

17. Al-Aidaroos, A.M. and F.M. Ghazali, 1998. Zooplankton of highly eutrophic, sewage polluted coastal lagoons off Jeddah, central red sea. J. King Abdulaziz Univ. Mar. Sci. Jeddah, 9: 131-148. http://md1.csa.com/partners/viewrecord.php?reque ster $=$ gs \&collection $=$ ENV \& recid $=5383349 \& q=Z$ zoo plankton+of+highly+eutrophic $\% 2 \mathrm{C}+$ sewage+pollu ted+coastal+lagoons+off+Jeddah $\% 2 \mathrm{C}+$ central+red + sea\&uid $=788100800 \&$ setcookie $=$ yes

18. Shaikh, E.A.1, J.C. Roff and N.M. Dowidar, 2004. Phytoplankton ecology and production in the Red Sea off Jiddah, Saudi Arabia. Mar. Bbiol., 92: 405-416. http://cat.inist.fr/?aModele $=$ afficheN\&cpsidt $=8042$ 325

19. Baker, M. and C.F.H. Hosny, 2005. Zooplankton diversity and abundance in half moon bay, Saudi coastal waters, Arabian Gulf. Sci. J. King Faisal Univ. Basic Applied Sci., 6: 1-30.

20. Al-Fredan, M.A. and A.A. Fathi, 2007. Preliminary survey of Edaphic Algae in Al-Hassa Region, Saudi Arabia. Pak. J. Biol. Sci., 10: 3210-3214. http://www.ncbi.nlm.nih.gov/pubmed/19090128

21. Strickland, J.D.H. and T.R. Parsons, 1972. A Practical Handbook of Sea Water Analysis. 2nd Edn., Fish Research, Bull, Canada, pp: 310. http://sirislibraries.si.edu/ipac20/ipac.jsp?uri=full=3100001 ! 50168!0\#focus

22. Adams, V.D., 1991. Water and Wastewater Examination Manual. Lewis Publishers, Inc., USA., ISBN: 10: 0873711998, pp: 264. 
23. Golterman, H.L. and R.S. Clymo, 1971. Methods for Chemical Analysis of Fresh Water. IBP n. 8. Blackwell, Oxford, pp: 166.

24. Utermöhl, H., 1958. Quantitative Methoden Utersuchung des Nannoplankton in Adderheldens. Handbuch der Biolog-Arb-Methoden Abt.IX (1).

25. Willén, E., 1976. A simplified method of phytoplankton counting. Br. J. Phycol., 11: 265-278.

26. Hobro, R. and E. Willen, 1977. Phytoplankton counting. In tercalibration results and recommendations for routine work. Int. Revue Ges. Hydrobiol., 62 : 605-811.

27. Smith, G.M., 1950. The fresh water algae of the United States. 2nd Edn., McGraw-Hill Co., New York, pp: 719.

http://www.librarything.com/work/1882290

28. Fott, B., 1972. Das Phytoplankton des Sûsswassers. 6-Chlorophyceae, Ordnung. Tetrasporales. Stuttgart, pp: 116.

29. Bourrelly, P., 1981. Les algues d'eau douce. Initiation a'la sestematique. Tome II: Chrysophyce'es, Phyeophyc'es, Xanthopyce'es et Diatome'es. N. Boube's and Co., Paris, pp: 517.

30. Prescott, G.W., 1987. How to Know the Fresh Water Algae. Wm. C. Brown Company Publishers, Dubuque Lowe, pp: 293

31. Pielou, E.C., 1966. The measurement of diversity in different types of biological collections. J. Theor. Biol, 13: 131-144.

32. Fenaux, R., 1967. Les Appendiculaires des mer d'Europe et du Bassin Méditerranéen. Masson and Cie Editeurs, Paris.

33. Tregouboff, G. and M. Rose, 1978. Manual de planctologie Méditerranéenne. Du CNRS, France.

34. Fathi, A.A. and I.A. Kobbia, 2000. Hydrobiological investigation of Abou-Median lake, El-Minia, Egypt. Bull. Fac. Sci., Assiut. Univ., 29: 77-91.

35. Fathi, A.A, H.M. Abdelzaher, R. Flower, M. Ramdani and M. Kraiem, 2001. Phytoplankton communities in North African wetland lakes: The CASSARINA Project. Aquatic Ecol., 35: 303-318. http://www.pressekatalog.de/Phytoplankton+comm unities+of+North+African+wetland+lakes+the+CA SSARINA+Project/ARTID_10.1023/A:101198872 2774.html

36. Fathi, A.A. and R.J. Flower, 2005. Water quality and phytoplankton communities in lake qarun (Egypt). Aquatic Sci., 67: 350-362. http://cat.inist.fr/?aModele $=$ afficheN\&cpsidt $=17157642$

37. Ruttner, F., 1963. Fundamental of Limnology. University of Toronto Press, Buffalo: pp: 307. http://orton.catie.ac.cr/cgi-

bin/wxis.exe/?IsisScript=QUV.xis\&method $=$ post $\&$ formato $=2 \&$ cantidad $=1 \&$ expresion $=m f n=002356$
38. Almohandis, A.A., 1991. Elemental and geochemical analysis of the umm-khurisan spring water (Al-Hasa Area, Eastern province, Saudi Arabia). Int. J. Environ. Anal. Chem., 43: 277-283. http://cat.inist.fr/?aModele $=$ afficheN\&cpsidt $=11499190$

39. Al-Nabulsi, Y.A., 2001. Saline drainage water, irrigation frequency and crop species effects on some physical properties of soils. J. Agron. Crop Sci., 186: 15-20.

http://cat.inist.fr/?aModele $=$ afficheN\&cpsidt $=961830$

40. Allott, N.A., 1986. Temperature, oxygen and heatbudgets of six small western Irish lakes. Freshwater Biol., 16: 145-154. DOI: 10.1111/j.1365-2427.1986.tb00959.x

41. Mohammed, A.A. and A.A. Fathi, 1990. The condition of the Nile in the years 1968-1978. Bull. Fac. Sci. Assiut. Univ., 19: 141-164.

42. Kobbia, I.M., R.M. Metwali and H.M. El-Adel, 1995. Influence of water effluents of soap and oil factory at Benha on Nile phytoplankton communities. Egypt J. Bot., 35: 45-57.

43. Badawy, M.I., R.A. Wahaab and H.F. Abou Waly, 1995. Petroleum and chlorinated hydrocarbons in water from Lake Manzala and associated canals. Bull Environ. Cont. Toxicol, 55: 258-263. http://www.ncbi.nlm.nih.gov/pubmed/7579932

44. El-Nagar, M.E.E., S.A. Shaaban-Dessouki, M.I. Abdel-Hamid and E.M. Aly, 1997. Effect of treated sewage on the water quality and phytolankton populations of Lake Manzala (Egypt) with emphasis on biological assessment of water quality. New Microbiol., 20: 253-276. http://cat.inist.fr/?aModele=afficheN\&cpsidt=2783113

45. El-Nagar, M.E.E., D.S.A. Shaaban, M.I. AbdelHamid and E.M. Aly, 1998. Studies on the phytoplankton population and physico-chemical conditions of treated sewage discharged into lake Manzala in Egypt. Microbiologia (Pavia), 21: 183-196.

46. Fathi, A.A. and H.M.A. Abdelzahar, 2000. Site description for the Egyptian lakes and results of water chemistry and phytoplankton for CASSARINA lakes. Unpublished Final Report to the EU Commission, University of El Minia.

47. Talling, J.F., 1976. Water Characteristics. In: The Nile, Biology of an Ancient River, Junk, Rzoska J. (Ed.). The Hague.

48. Abdel-Satar, A.M., 1998. Distribution of some chemical elements in river nile at great cairo region. Ph. D. Thesis, Faculty of Science, Cairo University, pp: 249.

49. Abdel-Satar, A.M. and A. Elewa, 2001. Water quality and environmental assessments of the River Nile at Rosette branch. Proceeding of the 2nd Conference and exhibition for life and Environment, Apr. 3-5, Alexandria, pp: 136-164. 
50. Gharib, S.M. and A.M. Soliman, 1998. Some water characteristics and phyto-Zooplankton relationship in Lake Edku (Egypt) and Adjacent Sea. Bull. Faci. Sci. Alex. Univ., 38: 25-44.

51. El-Garawany, M.M., M.A. Al-Eed and F.N. Assubaie, 2005. Determination of nitrate and nitrite levels in soil and groundwater in Al Hassa area, Saudi Arabia. Sci. J. King Faisal Univ. Basic Applied Sci., 6: 87-97. http://www.kfu.edu.sa/sjournal/eng/pdffiles/2626.pdf

52. Hussein, A.B., 1989. Ecological studies in pond Ismaelia in El-Minia Province (Egypt). M.Sc. Thesis, Zoology Department, Faculty of Science, El-Minia University, Egypt.

53. Goldman, C.R. and A.J. Horne, 1983. Limnology. Mc Graw-Hill Book Company, New York, USA., pp: $\quad 464 . \quad$ http://bases.bireme.br/cgibin/wxislind.exe/iah/online/?IsisScript=iah/iah.xis $\& s r c=$ google $\&$ base $=$ REPIDISCA\&lang $=p \& n e x t A$ ction=lnk\&exprSearch=133752\&indexSearch=ID

54. Cole, G.A., 1983. Textbook of Limnology. 3rd Edn., CV Mosby Company, St. Louis, Toronto London, ISBN: 10: 0801610044, pp: 401.

55. Talling, J.F. and I.B. Talling, 1965. The chemical composition of African lake waters. Int. Rev. Gesamten Hydrobiol., 50: 421-463. DOI: 10.1002/iroh.19650500307

56. Fathi, A.A and F.E.T. Zaki, 1999. Effects of wastewater discharge into the river Nile on the water quality and phytoplankton communities at El-Minia, Egypt. Bull. Fac. Sci. El-Minia Univ. (Egypt), 12: 99-110.

57. Aly, M.M. and M.M. Yahya, 2002. Impacts of chemical and microbiological pollutants on water quality of natural protected area: Lake Burullus. Eng. Res. J., 84: 87-108.

58. Fathi, A.A. and H.M. Abdelzahaher, 2003. Limnological studies on wetland lake El-Manzala, Egypt. Bull. Fac. Sci. Assiut. Univ., 32: 215-233.
59. Nygaard, G., 1978. Freshwater phytoplankton from the Narssaq Area, South Greenland. Bot. Tidsskrift (Denmark), 73: 191-238. http://www.fao.org/agris/search/display.do?f=./197 9/v505/XE7920761.xml;XE7920761

60. Sabae, S.Z. and S.A. Rabeh, 2000. Bacterial indices of sewage pollution in Lake Qarun, ElFayoum, Egypt. Egypt J. Aquat. Biol. Fish., 4: 103-116.

61. Shaaban, A.S., A.A. Badawi and A.A. El-Awamry, 1985. Studies on the diatoms of Bahr Youssef irrigated canal and its branches in El-Fayoum depression (ARE). Moshtohor Ann. Agric. Sci., 24: 7-33.

62. Soliman, G.F., 1990. Observations on some Physical conditions of lake Qarun. Proceeding of the Regional Symposium Environmental Studies (UNARC), Alexandra, pp: 588-601.

63. Staub, R., J.W. Appling, A.M. Hofstetter and I.J. Haas, 1970. The effects of industrial wastes of Memphis and Shelby on primary planktonic producers. Bioscience, 20: 905-912. http://www.eric.ed.gov/ERICWebPortal/custom/po rtlets/recordDetails/detailmini.jsp?_nfpb=true\&_\& ERICExtSearch_SearchValue_0=EJ026247\&ERIC ExtSearch_SearchType_0=no\&accno=EJ026247

64. Al-Asgah, N.A., A.B. Adam and K.M. Bedawi, 1989. A Check list of zooplankton species in Saudi Arabia. J. King Saud Univ., Sci., 1: 35-41. http://digital.library.ksu.edu.sa/paper591.html 